\title{
Analysis of vascularized fibula graft integration to the extracorporeal irradiated bone after replantation: 2-year follow-up
}

\author{
Análise da integração do enxerto de fíbula vascularizada ao osso irradiado extracorpóreo após reimplante: \\ acompanhamento de 2 anos
}

Análisis de la integración del injerto de peroné vascularizado en el hueso irradiado extracorpóreo después del reimplante: seguimiento de 2 años

Luis Guilherme Rosifini ALVES REZENDE ${ }^{1}$

Ricardo Alberto Lupinacci PENNO²

Edgard Eduard ENGEL ${ }^{3}$

Nilton MAZZER ${ }^{4}$

${ }^{I}$ Fellowship of Division of Hand Surgery and Microsurgery, General Hospital of the Medical School of Ribeirão Preto, University of São Paulo USP, HC-FMRP-USP 14049-900 Ribeirão Preto-SP, Brazil

${ }^{2}$ Assistant Physician of Division of Hand Surgery and Microsurgery, General Hospital of the Medical School of Ribeirão Preto - University of São Paulo USP, HC-FMRP-USP 14049-900 Ribeirão Preto-SP, Brazil

${ }^{3}$ Associated Professor and Head of Division of Oncologic Orthopedic Surgery, General Hospital of the Medical School of Ribeirão Preto - University of São Paulo USP, HC-FMRP-USP 14049-900 Ribeirão Preto-SP, Brazil

${ }^{4}$ Full Professor and Head of Division of Hand Surgery and Microsurgery, General Hospital of the Medical School of Ribeirão Preto - University of São Paulo USP, HC-FMRP-USP 14049-900 Ribeirão Preto-SP, Brazil

\begin{abstract}
Background: Major bone segmental defects in oncologic patients continue as a therapeutic challenge to orthopedic surgeons. The few alternatives for its management and the relationship between functional outcome and surgical complications remain among the main restrictions for the indication of different techniques. One of these alternatives is the vascularized fibular graft in association with the creation of a bone channel made from resection of the tumor bone segment after being submitted to the extracorporeal irradiation technique. There is little subject information about long-term follow-up either prospective than retrospective studies. Aim of the study: Retrospective evaluation of vascularized fibular graft union capacity from diaphysis and metaphysis and its integration to the irradiated bone after transplantation. Methods: Eleven patients submitted to extracorporeal irradiation technique and replantation with vascularized fibular graft had their radiographic images on 6,12 and 24 months of postoperative period evaluated. Results: We observed 45,4\% in diaphysis integration in the first year and $72,7 \%$ in the second year of follow-up, progressive in the diaphysis focus, and maintenance of the metaphysis focus (33,3\%). Conclusion: The fibula has a good capacity for bone integration, showing less influence on the union of the metaphysis portion.
\end{abstract}

Descriptors: Bone Transplantation; Osteosarcoma; Microsurgery; Surgical Oncology.

\section{Resumo}

Antecedentes: Os principais defeitos segmentares ósseos em pacientes oncológicos continuam como um desafio terapêutico para os cirurgiões ortopédicos. As poucas alternativas para seu manejo e a relação entre resultado funcional e complicação cirúrgica permanecem entre as principais restrições para indicação de diferentes técnicas. Uma dessas alternativas é o enxerto fibular vascularizado, associado à criação de um canal ósseo feito a partir da ressecção do segmento ósseo tumoral após ser submetido à técnica de irradiação extracorpórea. Há pouca informação sobre o assunto em longo prazo, tanto em estudos prospectivos quanto em estudos retrospectivos. Objetivo do estudo: Avaliação retrospectiva da capacidade de consolidação do enxerto fibular vascularizado de diáfise e metáfise e sua integração ao osso irradiado após o transplante. Métodos: onze pacientes submetidos à técnica de irradiação extracorpórea e replantio com enxerto fibular Vascularizado tiveram suas imagens radiográficas nos 6, 12 e 24 meses de pós-operatório avaliados. Resultados: observamos $41,1 \%$ de integração no primeiro ano e 58,8\% no segundo ano de acompanhamento, progressivo no foco da diáfise e manutenção do foco da metáfise. Conclusão: A fíbula possui boa capacidade de integração óssea, mostrando menor influência na consolidação da porção metafísica.

Descritores: Transplante Ósseo; Osteossarcoma; Microcirurgia; Oncologia Cirúrgica.

\section{Resumen}

Antecedentes: los principales defectos del segmento óseo en pacientes oncológicos continúan como un desafío terapéutico para los cirujanos ortopédicos. Las pocas alternativas para su manejo y la relación entre el resultado funcional y la complicación quirúrgica permanecen entre las principales restricciones para la indicación de diferentes técnicas. Una de estas alternativas es el injerto vascularizado de peroné en asociación con la creación de un canal óseo a partir de la resección del segmento óseo tumoral después de someterse a la técnica de irradiación extracorpórea. Hay poca información de los sujetos sobre el seguimiento a largo plazo, ya sea prospectivo que los estudios retrospectivos. Objetivo del estudio: Evaluación retrospectiva de la capacidad de consolidación del injerto vascularizado de peroné de la diáfisis y la metafisis y su integración al hueso irradiado después del trasplante. Métodos: once pacientes sometidos a técnica de irradiación extracorpórea y reimplantación con injerto vascularizado de peroné tuvieron sus imágenes radiográficas en 6,12 y 24 meses de período postoperatorio evaluados. Resultados: observamos $41.1 \%$ de integración en el primer año y $58.8 \%$ en el segundo año de seguimiento, progresivo en el enfoque de diáfisis y mantenimiento del enfoque de metafisis. Conclusión: el peroné tiene una buena capacidad de integración ósea, mostrando menos influencia en la consolidación de la porción de la metáfisis.

Descriptores: Trasplante Óseo; Osteosarcoma; Microcirugia; Oncología Quirúrgica.

\section{INTRODUCTION}

Limb salvage is the standard technique for treating bone tumors since advances in chemotherapy and imaging have made this possible. There are synthetic and biological alternatives to replacing the resected bone segment.

Endoprosthetic reconstruction provides rapid return to limb function but presents high infection rates $(10 \%)$ and its survival through looseness or wear is limited. However, $25 \%$ of patients require revision procedures in 10 years ${ }^{1}$.
The use of autograft is a biological solution whereupon bone segmental defect is replaced by cadaveric bone. Despite prophylaxis, there are no warranties to run out the risk of disease transmission, and the risk of immediate postoperative infection is similar to the endoprosthesis. Another feared complication is graft fracture due to reabsorption occurring naturally in this devitalized bone segment. In addition, the difficulty of finding donor measures similar to the recipient requires the conservation of 
large numbers of bones in the bank ${ }^{2}$.

Extracorporeal irradiation and replantation is a technique in which the patient's own bone segment was replanted after cleansing the soft tissues and tumor tissue and after irradiation in sufficient doses to cause complete cellular necrosis. Complications are similar to allografts except for the risk of disease transmission and perfect adaptation to the replantation site. From the oncological point of view, especially the risk of local and distant recurrence, the risks are also similar ${ }^{3}$.

To promote the revitalization of the irradiated bone and to increase the mechanical stability of the reconstruction, a vascularized fibular graft can be implanted in the bone marrow channel. The major criticism of this alternative is the substantial increase in the complexity of surgery and surgical time $e^{4,5}$.

There are few data in the literature on the integration of the fibula and its effect on the union of the irradiated bone.

The aim of this study is the evaluation of the integration capacity of the vascularized fibular graft to the irradiated bone after replantation.

\section{MATERIAL AND METHOD}

This cross-sectional study was approved by

the Ethics Committee (CAAE:
02607218.2.0000.5440). Inclusion criteria were patients submitted to the vascularized fibular graft procedure for limb reconstruction after resection of malignant bone tumors greater than 8 centimeters of length. Exclusion criteria were cases where margin needs to be extended to amputation due to involvement or postoperative infection.

Twenty patients submitted to surgical treatment of malignant bone tumors using the extracorporeal irradiation by 50 Gray (Gy) and replantation technique with end-to-end arterial anastomosis from 2002 to 2011 had their medical records and radiographs analyzed. In nine cases it was not possible to evaluate all the data due to death or loss of radiographs films. In six cases, the irradiated bone included the articular surface and, therefore, presented only osteotomy at diaphysis. The radiographic films of the postoperative period were analyzed.

The patients were submitted to a preoperative assessment and evaluation of imaging exams to determine the length of the bone tumor, resection, and reconstruction plan. The distal and proximal bone margin was 2 centimeters to the tumor which allowed the resection of compartments margin. After resection, bone specimen was submitted to macroscopic removal of all visible tumor from its external cortical. Marrowbone reaming was also performed progressively. Irrigation with ten liters of saline was performed and the bone fragment was irradiated with 50 Gray for 120 minutes $^{6}$. A channel was made on the remaining bone to ensure that fibula could be inserted inside the marrow space ${ }^{7}$. During this procedure on the recipient side, a vascularized fibular graft was raised in the contralateral limb. The vascularized fibular graft was inserted into the bone channel and replantation of sterile bone with end-toend microsurgical anastomosis was performed.

The mean resected bone tumor length was $16,90 \mathrm{~cm}$ ranged from 9 to $20 \mathrm{~cm}$. Being $9 \mathrm{~cm}$ in the proximal humerus, $19 \mathrm{~cm}$ (ranged from 18 to $20 \mathrm{~cm}$ ) in the distal femur and $16,83 \mathrm{~cm}$ (ranged from 13 to $20 \mathrm{~cm}$ ) in the proximal tibia.

There were no control groups or comparisons with the results of another study, considering this a criticism of this study. The results were obtained through the evaluation of radiographic films.

The study group consisted of 11 patients with a mean age of 19,7years (11 to 53years) of whom five were males. The preponderant diagnosis was the classical osteosarcoma with eight cases and the remaining three being parosteal osteosarcoma, lymphoma, and leiomyosarcoma.

The postoperative protocol included an immediate rehabilitation program with toe-touch weight-bearing and full range of movement of joints. Partial weight-bearing was introduced after three months and full weight-bearing was permitted after evidence of union on radiographic films.

Radiographs films at 6,12, and 24 months of postoperative period were analyzed by three evaluators (one radiologist, one orthopedic surgeon, and one hand surgeon) independently, without identification of postoperative time and it was observed bone callus formation, union of osteotomy and signs of fibula integration. The fibula was considered integrated into the irradiated bone when it had bone bridges or fusion between the bones. The osteotomy focus was considered consolidated when it presented bone integration or complete disappearance of the osteotomy line.

\section{RESULTS}

The bone location of the tumor, diagnosis and length, and receptor artery of anastomosis are detailed in Table 1. Tables 2 and 3 present the indexes of integration, union, and presence of callus according to the bone location.

Fibular integration occurred in $45.4 \%$ in the diaphyseal focus and $33.3 \%$ in the metaphyseal focus in the first year. Integration was $72.7 \%$ in the diaphysis and $33.3 \%$ in the metaphysis in the second year after the operation.

Fibular integration observed in the first year had increased in percentage in the integration of the diaphyseal focus and remained resembling in metaphyseal focus (Figure 1). 
Table 1. Bone location, tumor diagnosis and receptor artery of anastomosis

\begin{tabular}{|c|c|c|}
\hline Bone & $\begin{array}{l}\text { Tumor and Length of } \\
\text { Resection }\end{array}$ & $\begin{array}{l}\text { Local of arterial } \\
\text { anastomosis }\end{array}$ \\
\hline Proximal Tibia & $\begin{array}{l}\text { Classic osteosarcoma }-13 \mathrm{~cm} \\
\text { Classic osteosarcoma }-15 \mathrm{~cm} \\
\text { Classic osteosarcoma }-16 \mathrm{~cm} \\
\text { Classic osteosarcoma }-18 \mathrm{~cm} \\
\text { Classic osteosarcoma }-19 \mathrm{~cm} \\
\text { Lymphoma - 20cm }\end{array}$ & $\begin{array}{l}\text { Anterior tibial artery } \\
\text { Posterior tibial artery } \\
\text { Anterior tibial artery } \\
\text { Posterior tibial artery } \\
\text { Anterior tibial artery } \\
\text { Peroneal Artery } \\
\end{array}$ \\
\hline Distal Femur & $\begin{array}{l}\text { Classic osteosarcoma }-18 \mathrm{~cm} \\
\text { Classic osteosarcoma }-20 \mathrm{~cm} \\
\text { Parostealosteosarcoma }-18 \mathrm{~cm} \\
\text { Leiomyosarcoma - } 20 \mathrm{~cm}\end{array}$ & $\begin{array}{l}\text { Deep femoral artery } \\
\text { Deep femoral artery } \\
\text { Deep femoral artery } \\
\text { Deep femoral artery }\end{array}$ \\
\hline Proximal Humerus & Classic osteosarcoma $-9 \mathrm{~cm}$ & Deep brachial artery \\
\hline
\end{tabular}

Table 2: Results on diaphyseal focus

\begin{tabular}{|c|c|c|c|}
\hline & $\begin{array}{l}\text { Signs of Fibula } \\
\text { Integration }\end{array}$ & $\begin{array}{l}\text { Signs of } \\
\text { Union }\end{array}$ & Bone Callus \\
\hline 6 Months & $3[11]$ & $4[11]$ & $1[11]$ \\
\hline 12 Months & $5[11]$ & $6[11]$ & $3[11]$ \\
\hline 24 Months & $8[11]$ & $9[11]$ & $7[11]$ \\
\hline
\end{tabular}

Table 3: Results on metaphyseal focus of Articular Segmental Bone

\begin{tabular}{llll}
\hline & $\begin{array}{l}\text { Signs of Fibula } \\
\text { Integration }\end{array}$ & $\begin{array}{l}\text { Signs of } \\
\text { Union }\end{array}$ & Bone Callus \\
\hline 6 Months & $2[6]$ & $1[6]$ & $0[6]$ \\
\hline 12 Months & $2[6]$ & $5[6]$ & $0[6]$ \\
\hline 24 Months & $2[6]$ & $5[6]$ & $1[6]$ \\
\hline
\end{tabular}

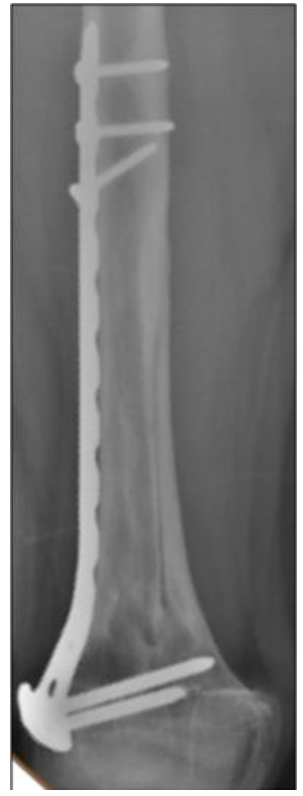

Figure 1: Integration of diaphysis focus and remained resembling in metaphysis focus.

\section{DISCUSSION}

The use of autografts has been addressed more broadly in the literature than the use of extracorporeal irradiation. The association of vascularized fibular graft to the irradiated bone is a little-studied subject and its radiological evaluation is made difficult because there are no well-established quantitative parameters for bone density and consolidation evaluation.

Non-union rates of the autografts were reported between $7.6 \%$ and $29.8 \%$, being higher in the diaphyseal bone and lower in the metaphyseal bone ${ }^{8-11}$. High union rates $(96 \%)$ were observed when there was an association between the autograft and the vascularized fibular graft $^{8}$. In a study evaluating the union of the irradiated and replanted bone, high rates of union (94\%) and hypertrophy were observed in cases where vascularized fibula was associated, and lower rates of union (75\%) when there was no association of the fibula vascularization or hypertrophy of the same?

In our study, it was also observed a shorter union time in the metaphyseal portion when compared to the diaphyseal portion. In the metaphyseal portion, the osteotomy was consolidated in five cases within 12 months of follow-up, whereas in this period the diaphyseal osteotomy was only consolidated in six patients. However, it was observed that there was an increase in the percentage of union of the diaphyseal osteotomy at 24 months of follow-up. The fibular integration occurred both in the metaphyseal bone and diaphyseal bone although integration was gradual on diaphyseal bone. The integration of the fibula allows to suppose that the bone has recovered its mechanical capacity and that the patient is able to return to its normal activity.

The limitations of this study are the small number of patients because death, loss of follow-up, radiographic examinations that couldn't be rescued, and no complications were reported. The individual timing of the weight-bearing of each patient was not reported. More studies are necessary to present the union percentage on a larger population, and a control group is necessary.

\section{CONCLUSION}

It was possible to identify that the fibula has a good capacity for integration in the bone. That allows supposing that bone recovered its mechanical capacity and that patients become able to return to normal activity. The fibula has no influence on the union in the metaphyseal focus and little collaboration with its revitalization.

\section{REFERENCES}

1. Myers GJ, Abudu AT, Carter SR, Tillman RM, Grimer RJ. The long-term results of endoprosthetic replacement of the proximal tibia for bone tumours. J Bone Joint Surg Br. 2007;89(12):1632-37.

2. Muscolo DL, Ayerza MA, Aponte-Tinao L, Farfalli G. Allograft reconstruction after sarcoma resection in children younger than 10 years old. Clin Orthop Relat Res. 2008;466(8):1856-62.

3. Puri A, Gulia A, Jambhekar N, Laskar S. The outcome of the treatment of diaphyseal primary bone sarcoma by resection, irradiation and reimplantation of the host bone: extracorporeal irradiation as an option for reconstruction in diaphyseal bone sarcomas. J Bone Joint Surg Br. 2012;94(7):982-88.

4. Hong AM, Millington S, Ahern V, McCowage G, Boyle R, Tatersall $\mathrm{M}$ et al. Limb preservation surgery with extracorporeal irradiation in the management of malignant bone tumor: the 
oncological outcomes of 101 patients. Ann Oncol. 2013;24(10):2676-80.

5. Manfrini M, Vanel D, De Paolis M, Malaguti C, Innocenti $M$, Ceruso $M$ et al. Imaging of vascularized fibula autograft placed inside a massive allograft in reconstruction of lower limb bone tumors. AJR Am J Roentgenol. 2004;182(4):963-70.

6. Spira E, Lubin E. Extracorporeal irradiation of bone tumor. A preliminary report. Isr J Med Sci. 1968;4(5):1015-19.

7. Capanna R, Bufalini C, Campanacci M. A new technique for reconstructions of large metadiaphyseal bone defects. Orthop Traumatol 1993;2:159-77.

8. Krieg AH, Davidson, AW, Stalley PD. Intercalary femoral reconstruction with extracorporeal irradiated autogenous bone graft in limb-salvage surgery. J Bone Joint Surg Br. 2007;89(3):366-71.

9. Ceruso M, Falcone C, Innocenti M, Delcroix L, Capanna R, Manfrini M. Skeletal reconstruction with a free vascularized fibula graft associated to bone allograft after resection of malignant bone tumor of limbs. Handchir Mikrochir Plast Chir. 2001;33(4):277-82.

10.Ortiz-Cruz E, Gebhardt MC, Jennings LC, Springfield DS, Mankin HJ. The results of transplantation of intercalary allografts after resection of tumors. A long-term follow-up study. J Bone Joint Surg Am. 1997;79(1):97-106.

11.Farfalli GL, Aponte-Tinao L, Lopez-Millán L, Averza MA, Muscolo DL. Clinical and functional outcomes of tibial intercalary allografts after tumor resection. Orthopedics. 2012;35(3):e391-96.

12. Aponte-Tinao L, Farfalli GL, Ritacco LE, Averza MA, Muscolo DL. Intercalary femur allografts are an acceptable alternative after tumor resection. Cln Orthop Relat Res. 2012;470(3):728-34.
CONFLICTS OF INTERESTS

The authors declare no conflicts of interests.

CORRESPONDING AUTHOR

\section{Luis Guilherme Rosifini Alves Rezende}

lgrezende@usp.br

Received 11/06/2019

Accepted 01/07/2019 